\title{
Virgibacillus halophilus sp. nov., spore-forming bacteria isolated from soil in Japan
}

Correspondence
Sun-Young An
an12su@hotmail.com

\author{
Sun-Young An, ${ }^{1}$ Mika Asahara, ${ }^{2}$ Keiichi Goto, ${ }^{2}$ Hiroaki Kasai ${ }^{3}$ \\ and Akira Yokota ${ }^{1}$ \\ ${ }^{1}$ Institute of Molecular and Cellular Biosciences, The University of Tokyo, Yayoi 1-1-1, \\ Bunkyo-Ku, Tokyo 113-0032, Japan \\ ${ }^{2}$ Microbiological and Analytical Group, Food Research Laboratories, Mitsui Norin Co. Ltd, \\ 223-1 Miyahara, Fujieda, Shizuoka 426-0133, Japan
}

${ }^{3}$ Marine Biotechnology Co. Ltd, 3-75-1 Heita, Kamaishi, Iwate 026-0001, Japan

Two Gram-positive, round-spore-forming, rod-shaped, halophilic bacterial strains, 5B73C ${ }^{\top}$ and 5B133E, were isolated from field soil in Kakegawa, Shizuoka, Japan, and were characterized taxonomically using a polyphasic approach. These two strains were found to comprise strictly aerobic, motile rods that formed subterminal endospores. Phylogenetic analyses based on 16S rRNA gene sequences showed that strains $5 B 73 C^{\top}$ and $5 B 133 E$ are phylogenetically affiliated to the genus Virgibacillus, exhibiting sequence similarities of $94.1-96.4 \%$ with respect to the type strains of Virgibacillus species. The DNA G $+C$ contents of strains $5 \mathrm{~B}^{2} 3 \mathrm{C}^{\top}$ and $5 \mathrm{~B} 133 \mathrm{E}$ were 42.6 and $42.3 \mathrm{~mol} \%$, respectively. The cell-wall peptidoglycan type (meso-diaminopimelic acid), the major cellular fatty acids (anteiso- $C_{15: 0}$, iso- $C_{15: 0}$, anteiso- $C_{17: 0}$ and iso- $C_{16: 0}$ ) and the quinone type (MK-7) of the isolates support their affiliation to the genus Virgibacillus. On the basis of their genotypic and phenotypic characteristics, the isolates represent a novel species of the genus Virgibacillus, for which the name Virgibacillus halophilus sp. nov. is proposed. The type strain is $5 B 73 C^{\top}\left(=\right.$ IAM $15308^{\top}=$ KCTC $\left.13935^{\top}\right)$.

The genus Virgibacillus was emended from Bacillus pantothenticus on the basis of amplified DNA restriction analysis results, fatty acid profiles, SDS-PAGE patterns of whole-cell proteins and phenotypic characterization (Heyndrickx et al., 1998). The genus Virgibacillus currently consists of 10 recognized species (Heyndrickx et al., 1999; Heyrman et al., 2003; Lee et al., 2006; Yoon et al., 2004, 2005), with Virgibacillus pantothenticus as the type species. The members of the genus Virgibacillus are motile, Grampositive rods that bear oval to ellipsoidal endospores. They have DNA G $+\mathrm{C}$ contents ranging from 36 to $43 \mathrm{~mol} \%$, their cell walls contain peptidoglycan of the mesodiaminopimelic type and they possess anteiso- $\mathrm{C}_{15: 0}$ as the major cellular fatty acid (Heyrman et al., 2003). Here, we report two novel strains, $5 \mathrm{~B} 73 \mathrm{C}^{\mathrm{T}}$ and $5 \mathrm{~B} 133 \mathrm{E}$, isolated from field soil in Kakegawa, Shizuoka, Japan, in the course of an environmental investigation and characterized phenotypically, chemotaxonomically and in terms of their 16S rRNA gene sequences.

Strains 5B73C $\mathrm{C}^{\mathrm{T}}$ and 5B133E were isolated by suspending soil samples in a $0.9 \% \mathrm{NaCl}$ solution and heating the suspension

The GenBank/EMBL/DDBJ accession numbers for the 16S rRNA gene sequences of strains $5 B 73 C^{\top}$ and $5 B 133 E$ are $A B 243851$ and AB243853, respectively. at $80{ }^{\circ} \mathrm{C}$ for $10 \mathrm{~min}$. The suspension was diluted serially, spread on plate count agar (Merck) and incubated at $35^{\circ} \mathrm{C}$. Purified colonies were selected, and all cultivations and phenotypic tests were carried out in media containing $50 \%$ Herbst's artificial seawater and incubated at $30{ }^{\circ} \mathrm{C}$. Herbst's artificial seawater contains the following (per litre distilled water): $\mathrm{NaCl}, 30 \mathrm{~g} ; \mathrm{KCl}, 0.7 \mathrm{~g} ; \mathrm{MgSO}_{4} .7 \mathrm{H}_{2} \mathrm{O}, 5.3 \mathrm{~g}$; $\mathrm{CaSO}_{4} \cdot 2 \mathrm{H}_{2} \mathrm{O}, 1.3 \mathrm{~g}$; and $\mathrm{MgCl}_{2} \cdot 6 \mathrm{H}_{2} \mathrm{O}, 10.8 \mathrm{~g}$. Cell morphology and motility were examined by using phasecontrast microscopy (BX60 microscope; Olympus). Growth under anaerobic conditions was determined after 1 week incubation in an AnaeroPack (Mitsubishi Gas Chemical). Catalase was determined with $3 \% \mathrm{H}_{2} \mathrm{O}_{2}$, the production of bubbles representing a positive reaction. Oxidase was determined using cytochrome oxidase paper (Nissui Pharmaceutical). API 20E and API $50 \mathrm{CH}$ microtest galleries (bioMérieux) were used to determine physiological and biochemical characteristics. The API tests were read after $48 \mathrm{~h}$. The isolates were Gram-positive and strictly aerobic, and the cells were motile and rod-shaped. Morphological and physiological characteristics of the isolates are given in the species description. The isolates were similar to Virgibacillus species in terms of morphological and some physiological characteristics, but were distinct regarding anaerobic growth, growth temperature, nitrate reduction and $\mathrm{H}_{2} \mathrm{~S}$ production (Table 1 ). 
Table 1. Differential characteristics of strain $5 B 73 C^{\top}$ and related Virgibacillus species

Taxa: 1, strain 5B73C ; 2, V. pantothenticus (Heyndrickx et al., 1999); 3, V. proomii (Heyndrickx et al., 1999); 4, Virgibacillus dokdonensis (Yoon et al., 2005; acid production from carbohydrates determined in this study); 5, Virgibacillus salexigens (Heyrman et al., 2003); 6, V. marismortui (Heyrman et al., 2003); 7, V. carmonensis (Heyrman et al., 2003); 8, Virgibacillus necropolis (Heyrman et al., 2003); 9, V. halodenitrificans (Yoon et al., 2004; Lee et al., 2006); 10, Virgibacillus koreensis (Lee et al., 2006).+, Positive; -, negative; V, variable; W, weakly positive.

\begin{tabular}{|c|c|c|c|c|c|c|c|c|c|c|}
\hline Characteristic & 1 & 2 & 3 & 4 & 5 & 6 & 7 & 8 & 9 & 10 \\
\hline Spore shape $e^{\star}$ & $\mathrm{E}$ & $\mathrm{E}, \mathrm{S}$ & E, $S$ & $\mathrm{E}, \mathrm{S}$ & $\mathrm{E}$ & $\mathrm{E}$ & E, $S$ & $\mathrm{E}$ & $\mathrm{E}$ & $\mathrm{E}$ \\
\hline Spore position $\dagger$ & $\mathrm{S}$ & $\mathrm{T}, \mathrm{S}$ & $\mathrm{T}, \mathrm{S}$ & $\mathrm{T}, \mathrm{S}$ & $\mathrm{C}, \mathrm{S}, \mathrm{T}$ & $\mathrm{T}, \mathrm{S}$ & S & $\mathrm{C}, \mathrm{S}, \mathrm{T}$ & $\mathrm{T}, \mathrm{S}$ & $\mathrm{T}$ \\
\hline Anaerobic growth & - & + & + & + & - & - & - & - & + & + \\
\hline Temperature for growth $\left({ }^{\circ} \mathrm{C}\right)$ & $5-45$ & $15-50$ & $15-50$ & $15-50$ & $15-45$ & $15-50$ & $10-40$ & $10-40$ & $10-45$ & $10-45$ \\
\hline Nitrate reduction & + & - & - & - & - & + & + & + & + & - \\
\hline $\mathrm{H}_{2} \mathrm{~S}$ production & - & + & - & - & + & - & - & - & - & - \\
\hline \multicolumn{11}{|l|}{ Acid production from: } \\
\hline$N$-Acetylglucosamine & + & + & + & + & $\mathrm{W}$ & + & - & $\mathrm{W}$ & + & - \\
\hline Amygdalin & - & + & - & - & $\mathrm{W}$ & - & - & - & - & + \\
\hline D-Arabinose & - & + & - & - & - & - & - & - & - & - \\
\hline Galactose & $\mathrm{w}$ & - & + & + & $\mathrm{W}$ & - & - & - & + & - \\
\hline D-Glucose & + & - & + & + & $\mathrm{W}$ & + & - & $\mathrm{W}$ & + & $\mathrm{W}$ \\
\hline D-Fructose & + & - & + & + & $\mathrm{W}$ & + & - & $\mathrm{W}$ & + & + \\
\hline L-Fucose & - & + & - & - & - & - & - & - & - & - \\
\hline Glycerol & $\mathrm{W}$ & + & - & + & - & $\mathrm{W}$ & - & $\mathrm{W}$ & $\mathrm{W}$ & - \\
\hline myo-Inositol & - & - & + & + & - & - & - & - & - & - \\
\hline D-Mannose & + & - & + & + & $\mathrm{w}$ & + & - & $\mathrm{W}$ & + & - \\
\hline L-Rhamnose & - & + & $\mathrm{V}$ & - & - & - & - & - & - & - \\
\hline D-Trehalose & + & + & + & - & - & - & - & $\mathrm{W}$ & + & $\mathrm{w}$ \\
\hline D-Turanose & - & + & - & - & - & - & - & - & - & - \\
\hline DNA G $+\mathrm{C}$ content $(\mathrm{mol} \%)$ & 42.6 & $36.9-38.3$ & $36.8-37.0$ & 36.7 & $36.3-39.5$ & $39.0-42.8$ & 38.9 & 37.3 & $38-39$ & 41 \\
\hline
\end{tabular}

${ }^{\star}$ E, Ellipsoidal; S, spherical.

$\dagger$ C, Central; S, subterminal; T, terminal.

On the basis of analyses of partial 16S rRNA gene sequences (Goto et al., 2000, 2002), the strains were grouped within the Virgibacillus cluster. However, they were found to be distinct from previously described species of the genus Virgibacillus. $16 S$ rRNA gene sequences were determined using an Applied Biosystems 16S rRNA gene kit, according to the instructions of the manufacturer. The 16S rRNA gene sequences of strains $5 \mathrm{~B} 73 \mathrm{C}^{\mathrm{T}}$ and $5 \mathrm{~B} 133 \mathrm{E}$ were compared with sequences obtained from GenBank. The sequences were aligned with the CLUSTAL W software package (Thompson et al., 1994), and evolutionary distances and $K_{\text {nuc }}$ values (Kimura, 1980) were generated. Alignment gaps and ambiguous bases were not taken into consideration. A phylogenetic tree was constructed using the neighbour-joining method (Saitou \& Nei, 1987), and the topology of the phylogenetic tree was evaluated by using the bootstrap resampling method of Felsenstein (1985), based on 1000 replicates. Similarity values were calculated using MEGA3 (Kumar et al., 2004). Almost-complete 16S rRNA gene sequences of strains $5 \mathrm{~B} 73 \mathrm{C}^{\mathrm{T}}$ and $5 \mathrm{~B} 133 \mathrm{E}$ were determined and subjected to a comparative analysis. The $16 \mathrm{~S}$ rRNA gene sequences of the two isolates shared $100 \%$ similarity and were on the same phylogenetic branch. Strain $5 \mathrm{~B} 73 \mathrm{C}^{\mathrm{T}}$ showed the highest level of 16S rRNA gene sequence similarity with Virgibacillus marismortui (96.4\%), followed by Virgibacillus carmonensis (96.2\%), Virgibacillus halodenitrificans (96.2\%) and Virgibacillus proomii (95.9\%). On the other hand, the strains showed lower levels of sequence similarity ( <95\%) with respect to other recognized low-G $+\mathrm{C}$, Gram-positive species, including Lentibacillus salarius (94.9\%), Lentibacillus salicampi (94.0\%) and Oceanobacillus iheyensis (94.0\%). Generally, around $95 \%$ would be a practicable border zone for genus definition (Ludwig et al., 1998). The phylogenetic tree shown in Fig. 1 indicates that strains $5 \mathrm{~B} 73 \mathrm{C}^{\mathrm{T}}$ and $5 \mathrm{~B} 133 \mathrm{E}$ are closely related to the genus Virgibacillus but form a separate clade within that genus.

The 16S rRNA gene sequence similarity of type strains of Virgibacillus species with respect to $5 \mathrm{~B} 73 \mathrm{C}^{\mathrm{T}}$ lies between 94.1 and $96.4 \%$. The overall genomic DNA relatedness of $5 \mathrm{~B} 73 \mathrm{C}^{\mathrm{T}}$ with respect to these species may not be high because, as Stackebrandt \& Goebel (1994) observed, strains with less than $97 \% 16$ S rRNA gene sequence similarity have DNA-DNA relatedness values below $70 \%$. Thus, in the 


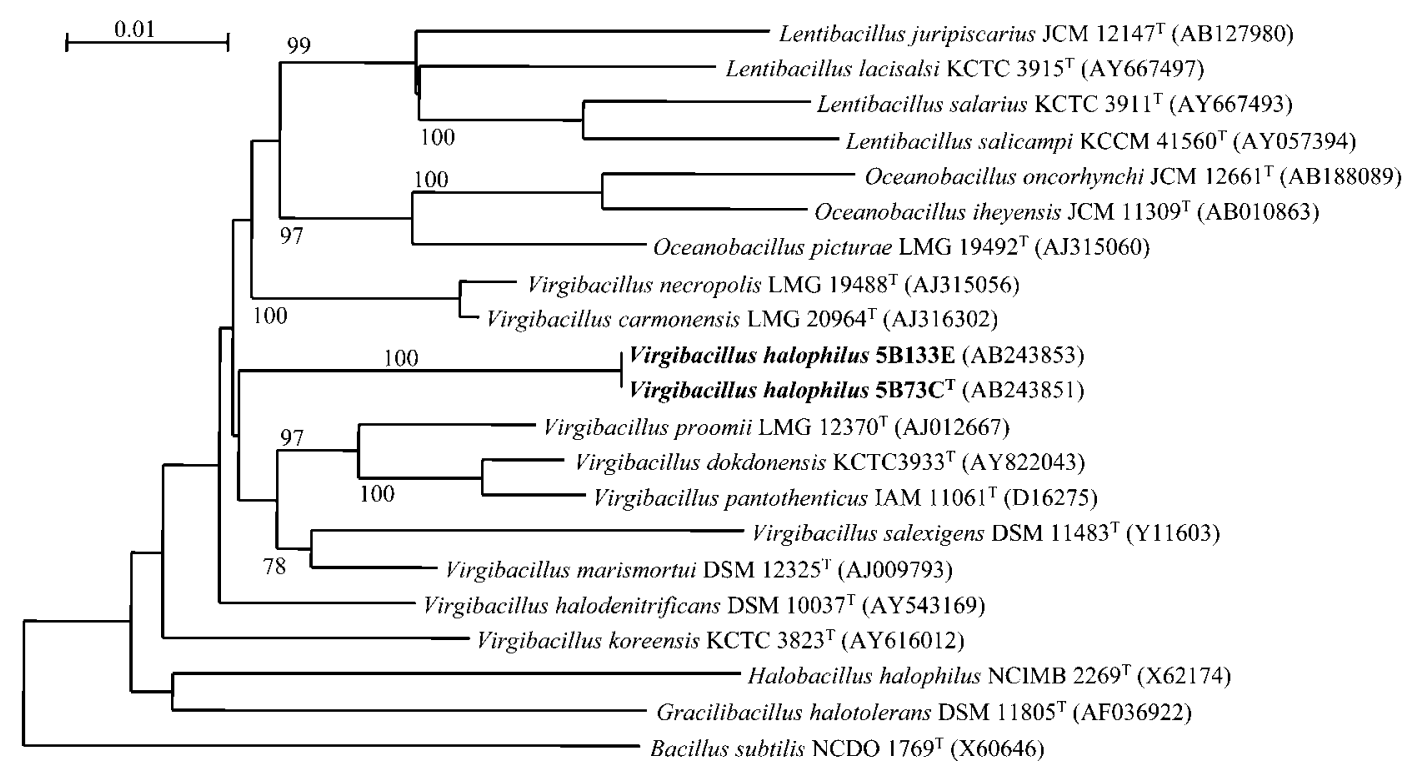

Fig. 1. Neighbour-joining phylogenetic tree, based on $16 \mathrm{~S}$ rRNA gene sequences, showing the positions of strains $5 B 73 C^{\top}$, $5 \mathrm{~B} 133 \mathrm{E}$ and related taxa. Numbers at the nodes indicate the percentages of occurrence in 1000 bootstrapped trees; only values greater than $70 \%$ are shown. Bar, 1 substitution per $100 \mathrm{nt}$.

absence of a close relative showing significant $16 \mathrm{~S}$ rRNA gene sequence similarity, strains $5 B 73 \mathrm{C}^{\mathrm{T}}$ and $5 \mathrm{~B} 133 \mathrm{E}$ can be considered as representing a novel species.

Cellular fatty acids from strains $5 \mathrm{~B} 73 \mathrm{C}^{\mathrm{T}}$ and $5 \mathrm{~B} 133 \mathrm{E}$ grown on trypticase soy agar (BD BBL) for $48 \mathrm{~h}$ at $30^{\circ} \mathrm{C}$ were prepared, separated and identified with the Microbial Identification System (MIDI). The major fatty acids of strains $5 \mathrm{~B} 73 \mathrm{C}^{\mathrm{T}}$ and $5 \mathrm{~B} 133 \mathrm{E}$ were anteiso- $\mathrm{C}_{15: 0}$ (35.8$40.9 \%)$, iso- $\mathrm{C}_{15: 0}$ (21.2-20.6\%), anteiso- $\mathrm{C}_{17: 0}$ (16.1$19.9 \%)$ and iso- $\mathrm{C}_{16: 0}(10.3-6.5 \%)$. This fatty acid profile is quite similar to those of species of the genus Virgibacillus (Table 2).

Genomic DNA was prepared according to the method of Marmur (1961). The G $+C$ content of the total DNA was measured by HPLC according to the method described by Mesbah et al. (1989). The DNA G $+C$ contents of 5B73C ${ }^{T}$ and $5 \mathrm{~B} 133 \mathrm{E}$ were 42.6 and $42.6 \mathrm{~mol} \%$, which is a little higher than those for known species of the genus Virgibacillus (Table 1). DNA-DNA hybridization was performed by using the photobiotin-labelling method of Ezaki et al. (1989) with a multi-well plate reader (CytoFluoR; PerSeptive Biosystems). The DNA-DNA hybridization values for strains $5 \mathrm{~B} 73 \mathrm{C}^{\mathrm{T}}$ and $5 \mathrm{~B} 133 \mathrm{E}$ and for $5 \mathrm{~B} 133 \mathrm{E}$ and $5 \mathrm{~B} 73 \mathrm{C}^{\mathrm{T}}$ were 95.4 and $101.5 \%$, respectively. The two strains should therefore be considered as representing a single species (Stackebrandt et al., 2002).

Analysis of the cell-wall peptidoglycan of strain $5 \mathrm{~B} 73 \mathrm{C}^{\mathrm{T}}$ (selected as the representative strain for the two isolates) was carried out by using the methods of Schleifer \& Kandler (1972). Strain $5 B 73 C^{T}$ possessed the meso-diaminopimelictype cell wall. Analysis of the respiratory quinones of strain
$5 \mathrm{~B} 73 \mathrm{C}^{\mathrm{T}}$ was performed as described by Collins \& Jones (1981): the major isoprenoid quinone was MK-7.

On the basis of phenotypic, chemotaxonomic and phylogenetic data, we conclude that strains $5 \mathrm{~B} 73 \mathrm{C}^{\mathrm{T}}$ and $5 \mathrm{~B} 133 \mathrm{E}$ represent a novel species of the genus Virgibacillus, for which we propose the name Virgibacillus halophilus sp. nov.

\section{Description of Virgibacillus halophilus sp. nov.}

Virgibacillus halophilus (ha.lo.phi'lus. Gr. n. hals salt; Gr. adj. philos loving; N.L. masc. adj. halophilus salt-loving).

Cells are Gram-positive, strictly aerobic, motile rods $(0.5 \times 1.75 \mu \mathrm{m})$. Ellipsoidal spores are formed subterminally. Colonies grown on trypticase soy agar containing $50 \%$ Herbst's artificial seawater are circular, convex and pale yellow. The growth temperature and $\mathrm{pH}$ are $5-45^{\circ} \mathrm{C}$ and $5.0-10.0$, respectively. Growth occurs both in the absence of $\mathrm{NaCl}$ and in the presence of $18 \% \mathrm{NaCl}(\mathrm{w} / \mathrm{v})$. Catalase and oxidase activities are positive. $\mathrm{H}_{2} \mathrm{~S}$ and indole are not produced. Nitrate is reduced to nitrite whereas nitrite is not reduced. Acetoin is produced. Urease, gelatinase and $\beta$-galactosidase are hydrolysed. Negative for arginine dihydrolase, lysine decarboxylase, ornithine decarboxylase, tryptophan deaminase and citrate utilization. Acid is produced from glucose, fructose, mannose, mannitol, $\mathrm{N}$ acetylglucosamine, arbutin, aesculin, salicin, cellobiose, lactose, sucrose and trehalose, but not from erythritol, Darabinose, L-xylose, adonitol, methyl $\beta$-D-xyloside, sorbose, rhamnose, dulcitol, inositol, sorbitol, methyl $\alpha$-D-mannoside, methyl $\alpha$-D-glucoside, amygdalin, maltose, melibiose, inulin, melezitose, raffinose, starch, glycogen, xylitol, D-turanose, D-lyxose, D-tagatose, D-fucose, L-fucose, 
Table 2. Fatty acid compositions of strains $5 B 73 C^{\top}$ and 5B133E and related Virgibacillus species

Strains: 1, 5B73C $\mathrm{C}^{\mathrm{T}}$; 2, 5B133E; 3, V. pantothenticus KCTC $3539^{\mathrm{T}}$; 4, V. proomii KCTC $3822^{\mathrm{T}} ; 5, V$. dokdonensis KCTC $3933^{\mathrm{T}} ; 6, V$. salexigens $\mathrm{KCTC} 3844^{\mathrm{T}}$; 7, V. marismortui KCTC $3845^{\mathrm{T}}$; 8 , V. carmonensis KCTC $3819^{\mathrm{T}}$; 9, V. necropolis KCTC $3820^{\mathrm{T}}$; 10, V. halodenitrificans KCTC $3790^{\mathrm{T}} ; 11$, V. koreensis KCTC $3823^{\mathrm{T}}$. Data for strains $5 \mathrm{~B} 73 \mathrm{C}^{\mathrm{T}}, 5 \mathrm{~B} 133 \mathrm{E}$ and $V$. dokdonensis KCTC $3933^{\mathrm{T}}$ are from this study; all other data are from Lee et al. (2006). Data for fatty acids representing less than $0.5 \%$ are not shown.

\begin{tabular}{|c|c|c|c|c|c|c|c|c|c|c|c|}
\hline Fatty acid & 1 & 2 & 3 & 4 & 5 & 6 & 7 & 8 & 9 & 10 & 11 \\
\hline $\mathrm{C}_{14: 0}$ & 2.1 & 1.5 & & & 2.1 & & & & & & 1.8 \\
\hline $\mathrm{C}_{15: 0}$ & 1.4 & 0.7 & & & & & & & 0.9 & & 5.1 \\
\hline $\mathrm{C}_{16: 0}$ & 5.3 & 4.4 & 1.3 & 4.0 & 12.7 & 5.1 & 1.8 & 1.0 & 1.6 & 1.1 & 5.9 \\
\hline $\begin{array}{c}\mathrm{C}_{16: 1} \omega 7 c \\
\text { alcohol }\end{array}$ & & & & & & 0.9 & 1.1 & 6.5 & 2.4 & 3.1 & 3.4 \\
\hline $\mathrm{C}_{16: 1} \omega 11 c$ & & & & & & 0.6 & 0.6 & 0.6 & 1.0 & & 2.2 \\
\hline iso- $\mathrm{C}_{13: 0}$ & & & & & 1.0 & & & & & & \\
\hline $\begin{array}{c}\text { anteiso- } \\
\mathrm{C}_{13: 0}\end{array}$ & & & & & 1.8 & & & & & & \\
\hline iso- $\mathrm{C}_{14: 0}$ & 5.6 & 2.9 & 2.3 & 2.4 & 2.1 & 4.2 & 2.9 & 3.3 & 2.2 & 7.4 & 8.3 \\
\hline iso- $\mathrm{C}_{15: 0}$ & 21.2 & 20.6 & 7.1 & 15.1 & 15.5 & 34.0 & 39.0 & 5.7 & 3.8 & 2.4 & 6.1 \\
\hline $\begin{array}{c}\text { anteiso- } \\
\mathrm{C}_{15: 0}\end{array}$ & 35.8 & 40.95 & 55.3 & 38.5 & 47.0 & 30.5 & 33.9 & 58.3 & 67.9 & 51.8 & 43.4 \\
\hline iso- $\mathrm{C}_{16: 0}$ & 10.3 & 6.5 & 7.2 & 7.3 & 3.7 & 8.4 & 4.3 & 6.4 & 4.2 & 11.8 & 14.4 \\
\hline iso- $\mathrm{C}_{17: 0}$ & 1.8 & 1.6 & 2.0 & 6.3 & 2.4 & 5.6 & 5.6 & 0.9 & 0.9 & & \\
\hline $\begin{array}{c}\text { anteiso- } \\
\mathrm{C}_{17: 0}\end{array}$ & 16.1 & 19.92 & 24.0 & 24.9 & 11.5 & 9.3 & 8.6 & 11.1 & 12.2 & 19.5 & 7.0 \\
\hline $\begin{array}{l}\text { Summed } \\
\text { feature } 3^{*}\end{array}$ & & & & & & & & 5.0 & 2.1 & & \\
\hline $\begin{array}{l}\text { Summed } \\
\text { feature } 4^{\star}\end{array}$ & & & & & & & 0.7 & & & 1.6 & \\
\hline
\end{tabular}

${ }^{*}$ Summed features: $3, \mathrm{C}_{16: 1} \omega 7 c$ and/or iso- $\mathrm{C}_{15: 0} 2-\mathrm{OH} ; 4$, iso- $\mathrm{C}_{15: 0}$ 2-OH and/or $\mathrm{C}_{16: 1} \omega 7 t$.

D-arabitol, L-arabitol, gluconate, 2-ketogluconate or 5ketogluconate. Acid production from glycerol, L-arabinose, ribose, D-xylose, galactose and gentiobiose is weak. The cell wall contains peptidoglycan of the meso-diaminopimelic acid type. The major isoprenoid quinone system is MK-7. The major cellular fatty acids are anteiso- $\mathrm{C}_{15: 0}$, iso- $\mathrm{C}_{15: 0}$, anteiso- $\mathrm{C}_{17: 0}$ and iso- $\mathrm{C}_{16: 0}$. The genomic DNA $\mathrm{G}+\mathrm{C}$ content of the type strain is $42.6 \mathrm{~mol} \%$.

The type strain, $5 B 73 C^{\mathrm{T}}\left(=\mathrm{IAM} 15308^{\mathrm{T}}=\mathrm{KCTC} 13935^{\mathrm{T}}\right)$, was isolated from field soil in Kakegawa, Shizuoka, Japan.

\section{References}

Collins, M. D. \& Jones, D. (1981). Distribution of isoprenoid quinone structural types in bacteria and their taxonomic implications. Microbiol Rev 45, 316-354.

Ezaki, T., Hashimoto, Y. \& Yabuuchi, E. (1989). Fluorometric deoxyribonucleic acid-deoxyribonucleic acid hybridization in microdilution wells as an alternative to membrane filter hybridization in which radioisotopes are used to determine genetic relatedness among bacterial strains. Int J Syst Bacteriol 39, 224-229.

Felsenstein, J. (1985). Confidence limits on phylogenies: an approach using the bootstrap. Evolution 39, 783-791.

Goto, K., Omura, T., Hara, Y. \& Sadaie, Y. (2000). Application of the partial 16S rDNA sequence as an index for rapid identification of species in the genus Bacillus. J Gen Appl Microbiol 46, 1-8.

Goto, K., Mochida, K. M., Asahara, M., Suzuki, M. \& Yokota, A. (2002). Application of the hypervariable region of the $16 \mathrm{~S} \mathrm{rDNA}$ sequence as an index for the rapid identification of species in the genus Alicyclobacillus. J Gen Appl Microbiol 48, 243-250.

Heyndrickx, M., Lebbe, L., Kersters, K., De Vos, P., Forsyth, C. \& Logan, N. A. (1998). Virgibacillus: a new genus to accommodate Bacillus pantothenticus (Proom and Knight 1950). Emended description of Virgibacillus pantothenticus. Int J Syst Bacteriol 48, 99-106.

Heyndrickx, M., Lebbe, L., Kersters, K., Hoste, B., De Wachter, R., De Vos, P., Forsyth, G. \& Logan, N. A. (1999). Proposal of Virgibacillus proomii sp. nov. and emended description of Virgibacillus pantothenticus (Proom and Knight 1950) Heyndrickx et al. 1998. Int J Syst Bacteriol 49, 1083-1090.

Heyrman, J., Logan, N. A., Busse, H. J., Balcaen, A., Lebbe, L., Rodriguez-Diaz, M., Swings, J. \& De Vos, P. (2003). Virgibacillus carmonensis sp. nov., Virgibacillus necropolis sp. nov. and Virgibacillus picturae sp. nov., three novel species isolated from deteriorated mural paintings, transfer of the species of the genus Salibacillus to Virgibacillus, as Virgibacillus marismortui comb. nov. and Virgibacillus salexigens comb. nov., and emended description of the genus Virgibacillus. Int J Syst Evol Microbiol 53, 501-511.

Kimura, M. (1980). A simple method for estimating evolutionary rates of base substitutions through comparative studies of nucleotide sequences. J Mol Evol 16, 111-120.

Kumar, S., Tamura, K., Jakobsen, I. B. \& Nei, M. (2004). MEGA3: integrated software for molecular evolutionary genetics analysis and sequence alignment. Brief Bioinform 5, 150-163.

Lee, J. S., Lim, J. M., Lee, K. C., Lee, J. C., Park, Y. H. \& Kim, C. J. (2006). Virgibacillus koreensis sp. nov., a novel bacterium from a salt field, and transfer of Virgibacillus picturae comb. nov. with emended descriptions. Int J Syst Evol Microbiol 56, 251-257.

Ludwig, W., Strunk, O., Klugbauer, S., Klugbauer, N., Weizenegger, M., Neumaier, J., Bachleitner, M. \& Schleifer, K.-H. (1998). Bacterial phylogeny based on comparative sequence analysis. Electrophoresis 19, 554-568.

Marmur, J. (1961). A procedure for the isolation of deoxyribonucleic acid from microorganisms. J Mol Biol 3, 208-218.

Mesbah, M., Premachandran, U. \& Whitman, W. B. (1989). Precise measurement of the $\mathrm{G}+\mathrm{C}$ content of deoxyribonucleic acid by highperformance liquid chromatography. Int J Syst Bacteriol 39, 159-167.

Saitou, N. \& Nei, M. (1987). The neighbor-joining method: a new method for reconstructing phylogenetic trees. Mol Biol Evol 4, 406-425.

Schleifer, K. H. \& Kandler, O. (1972). Peptidoglycan types of bacterial cell walls and their taxonomic implications. Bacteriol Rev 36, 407-477.

Stackebrandt, E. \& Goebel, B. M. (1994). Taxonomic note: a place for DNA-DNA reassociation and 16S rRNA sequence analysis in the present species definition in bacteriology. Int J Syst Bacteriol 44, 846-849.

Stackebrandt, E., Frederiksen, W., Garrity, G. M., Grimont, P. A. D., Kämpfer, P., Maiden, M. C. J., Nesme, X., Rossello-Mora, R., Swings, J. \& other authors (2002). Report of the ad hoc committee for the re-evaluation of the species definition in bacteriology. Int J Syst Evol Microbiol 52, 1043-1047. 
Thompson, J. D., Higgins, D. G. \& Gibson, T. J. (1994). CLUSTAL W: improving the sensitivity of progressive multiple sequence alignment through sequence weighting, position-specific gap penalties and weight matrix choice. Nucleic Acids Res 22, 4673-4680.

Yoon, J. H., Oh, T. K. \& Park, Y. H. (2004). Transfer of Bacillus halodenitrificans Denariaz et al. 1989 to the genus Virgibacillus as
Virgibacillus halodenitrificans comb. nov. Int J Syst Evol Microbiol 54, 2163-2167.

Yoon, J. H., Kang, S. J., Lee, S. Y., Lee, M. H. \& Oh, T. K. (2005). Virgibacillus dokdonensis sp. nov., isolated from a Korean island, Dokdo, located at the edge of the East Sea in Korea. Int J Syst Evol Microbiol 55, 1833-1837. 